\title{
Identification and Characterization of a New Blast Resistance Gene Located on Rice Chromosome 1 Through Linkage and Differential Analyses
}

\author{
Menglan Zhu, Ling Wang, and Qinghua Pan
}

Laboratory of Plant Resistance and Genetics, College of Resources and Environment, South China Agricultural University, Guangzhou, China, 510642.

Accepted for publication 12 January 2004.

\begin{abstract}
Zhu, M., Wang, L., and Pan, Q. H. 2004. Identification and characterization of a new blast resistance gene located on rice chromosome 1 through linkage and differential analyses. Phytopathology 94:515-519.

The Chinese native cv. Q14 expresses a high level of resistance to many isolates of Pyricularia grisea collected from Japan, Thailand, and China. Q14 was crossed to an indica-susceptible cultivar, Q61. To rapidly determine the chromosomal location of the major resistance gene present in the cultivar, a linkage analysis using microsatellite markers was performed in the $F_{2}$ population segregating 3R:1S (resistant/susceptible) through bulked-segregant analysis (BSA) in combination with recessiveclass analysis (RCA). A total of 189 microsatellite markers selected from

mosome 1 showed positive and negative polymorphisms, respectively, for a resistance gene segregating in the population. To confirm the polymorphic markers, a total of 155 viable susceptible individuals were tested with the RCA approach. The markers RM151 and RM259 were found to link to the resistance gene with recombination frequencies of $11.9 \pm 2.8 \%$ and $9.7 \pm 8.0 \%$, respectively. For further characterization of the resistance gene, 3 resistance genes mapped on chromosome 1, as well as 15 major resistance genes that might be employed in the breeding program, were selected for differential tests with 85 Chinese isolates. The resistance gene identified in this research conveys reactions distinct from those conditioned by the 18 resistance genes. This new resistance gene tentatively was designated $P i 27(\mathrm{t})$.
\end{abstract} each chromosome equally (with $\approx 10$ centimorgans) were tested with the BSA approach. Only two markers, RM151 and RM259, located on chro-
Additional keyword: Oryza sativa.
Blast, caused by the fungus Pyricularia grisea (Cooke) Sacc., is among the most destructive diseases of rice (Oryza sativa L.) in most rice-growing areas worldwide (27). Heavy losses occur frequently in both tropical and temperate countries under diseaseconducive conditions $(5,7,33)$. Utilization of genetic resistance is the most effective and environmentally friendly strategy for control of the disease.

Recently, certain progress has been made in mapping rice blast resistance genes with molecular markers, which forms the foundation for marker-aided selection (MAS) in resistance breeding program as well as for map-based cloning of the resistance genes. Imbe et al. (13) identified Pi20 in the rice cv. IR24 on chromosome 12 through restriction fragment length polymorphism (RFLP) analysis using recombinant inbred lines (RILs). Leong et al. (18) identified a resistance gene, Pi-CO39, corresponding to avirulence gene Avrl-CO39, in cv. CO39 through linkage analysis in a $\mathrm{F}_{2}$ population from a cross between cvs. CO39 and 51583 with microsatellite and RFLP markers. Zhuang et al. (41) identified two single resistance genes, Pi24(t) and Pi25(t), in cvs. Zhong 156 and Gumei 2, respectively, through random amplified polymorphic DNA (RAPD) analysis using RILs. Ahn et al. (1) reported that Korean cv. Suweon 365 carries three major resistance genes, Pi18, Pi21(t), and Pi22(t), against Korean isolates $\mathrm{KI}-313$, KJ-101, and KJ-201, respectively, through linkage analysis with RFLP and microsatellite markers in an $F_{2}$ population derived from a cross of cvs. Suweon and Chucheongbyeo. Fujii et al. (8) identified a panicle blast resistance gene, $\mathrm{Pbl}$, in cv.

Corresponding author: Q. Pan; E-mail address: panqh@ scau.edu.cn

Publication no. P-2004-0323-02R

(C) 2004 The American Phytopathological Society
Asanohikari on chromosome 11 through RFLP analysis using an $\mathrm{F}_{2}$ population derived from a cross between the cultivar and Koshikikari. Tabien et al. (35) identified Pi-tql, Pi-tq5, Pi-tq6, and $P i-\operatorname{lm} 2$ on chromosomes 11, 6, 2, and 11, respectively, through RFLP analysis using RILs from a cross between cvs. Lemont (lm) and Teqing (tq). Fukuoka and Okuno (9) first identified a recessive field resistance gene, pi21, in Japanese upland rice cv. Owarihatamochi on chromosome 4 through quantitative trait loci (QTL) analysis with RFLP markers. Yang et al. (39) identified the resistance gene Pi25(t) in cv. Yunxi 2, which transferred resistance from a Yunnan upland cv. Sanbandqishiluo, on the long arm of chromosome 1, through RFLP and microsatellite analyses in an $\mathrm{F}_{2}$ population from a cross of cvs. Yunxi 2 and 91F14-4. Li et al. (19) identified the first resistance gene, PiD1(t), and Chen et al. (4) the second gene, PiD2(t), in indica cv. Digu on chromosome 2 and 6, respectively, through RFLP, microsatellite, and resistance gene analog (RGA) analyses. To add to 27 resistance genes reviewed by Pan et al. (31), more than 43 major blast resistance genes have been identified so far $(1,4$, $8,9,13,18,19,31,35,39,41)$.

The Yunnan upland rice cv. Q14 shows resistance to all the Japanese blast fungus races and many isolates collected from Thailand and China (Q. H. Pan, unpublished data). To effectively use its broad-spectrum resistance in a rice breeding program, it is important to tag the resistance gene or genes present in Q14 with molecular markers. In this research, we rapidly mapped a new resistance gene present in Q14 through bulked-segregant analysis (BSA) (23) coupled with recessive-class analysis (RCA) (40) approaches, and provided further evidence to distinguish the new resistance gene from other resistance genes mapped on the same chromosome, as well as 15 major resistance genes employed in the breeding programs through differential analysis with 85 Chinese isolates. 


\section{MATERIALS AND METHODS}

Plant materials. For tagging the resistance gene or genes, the japonica-resistant $\mathrm{cv}$. Q14 was crossed to an indica-susceptible cv. Q61 (Table 1). $\mathrm{F}_{2}$ seed were pregerminated by soaking in water at $25^{\circ} \mathrm{C}$ for $48 \mathrm{~h}$, then sown in a plastic pot (34 files by 15 rows) filled with black organic soil treated with fungicide solution. Each pot was placed in a plastic tray ( 58 by 38 by $8 \mathrm{~cm}$ ). To confirm the success of inoculation, the parental cultivars and a susceptible check, cv. Sariceltik, were sown at both ends of the $F_{2}$ population in a tray. After gene tagging, the parental cultivars, three cultivars each carrying a single resistance gene on the same chromosome, and 15 cultivars each carrying a single resistance gene were selected for subsequent differential tests of the resistance genes (Table 1). In this case, each cultivar was sown in a row in each tray. Seedlings were grown in a greenhouse at 20 to $35^{\circ} \mathrm{C}$ for $\approx 3$ weeks before inoculation.

Conidial inoculation and disease scoring. $P$. grisea isolate CHL0335, which showed distinct reactions on the parents, was selected for constructing a mapping population. Eighty-five isolates collected from Guangdong Province, China, in 2002 were selected for subsequent characterization of the resistance gene or genes identified in Q14 with other, related resistance genes. Inoculum was prepared from cultures grown on rice polish agar medium ( $20 \mathrm{~g}$ of rice polish powder, $2 \mathrm{~g}$ of yeast extract, and $11 \mathrm{~g}$ of agar per liter of tap water). Two agar scraps colonized by the isolates were placed symmetrically onto the new medium in a 10 -cm glass petri plate and incubated at $25^{\circ} \mathrm{C}$ for $\approx 10$ days, until the surface of the plate was almost covered with mycelial growth. The growth was gently scraped in sterilized distilled water with a metal spatula on a clean bench, and then the plate was placed on the sporulation incubator under dark blue light for 2 to 3 days to facilitate conidiation of the culture. The culture was flooded with distilled water and conidia were released by scraping. The suspension was filtered through gauze mesh, and $0.5 \%$ solution of gelatin (DGF STOESS, Germany) was added as a surfactant. The concentration of conidia ranged from $1 \times 10^{5}$ to $5 \times 10^{5}$ conidia $\mathrm{ml}^{-1}$.

Seedlings were transferred into an inoculation incubator at the four- to six-leaf stage and inoculated by spraying 70 to $80 \mathrm{ml}$ of spore suspension per tray. After inoculation, the seedlings were kept in the inoculation incubator at $25^{\circ} \mathrm{C}$ with saturated humidity for $20 \mathrm{~h}$, then transferred to a moist vinyl tunnel at 25 to $30^{\circ} \mathrm{C}$. Disease reactions were scored $\approx 7$ days after inoculation by use of a 5-class scale described by Pan et al. (29).

DNA extraction and amplification. Total DNA was extracted from frozen leaves of rice plants according to Doyle and Doyle (6). Amplification reactions were performed with the GeneAmp

TABLE 1. Differential reactions of 4 rice cultivars carrying resistance genes on chromosome 1 and 15 cultivars carrying the main resistance genes on the other chromosomes, as well as an indica-susceptible cv. Q61, to some isolates of Pyricularia grisea selected from China

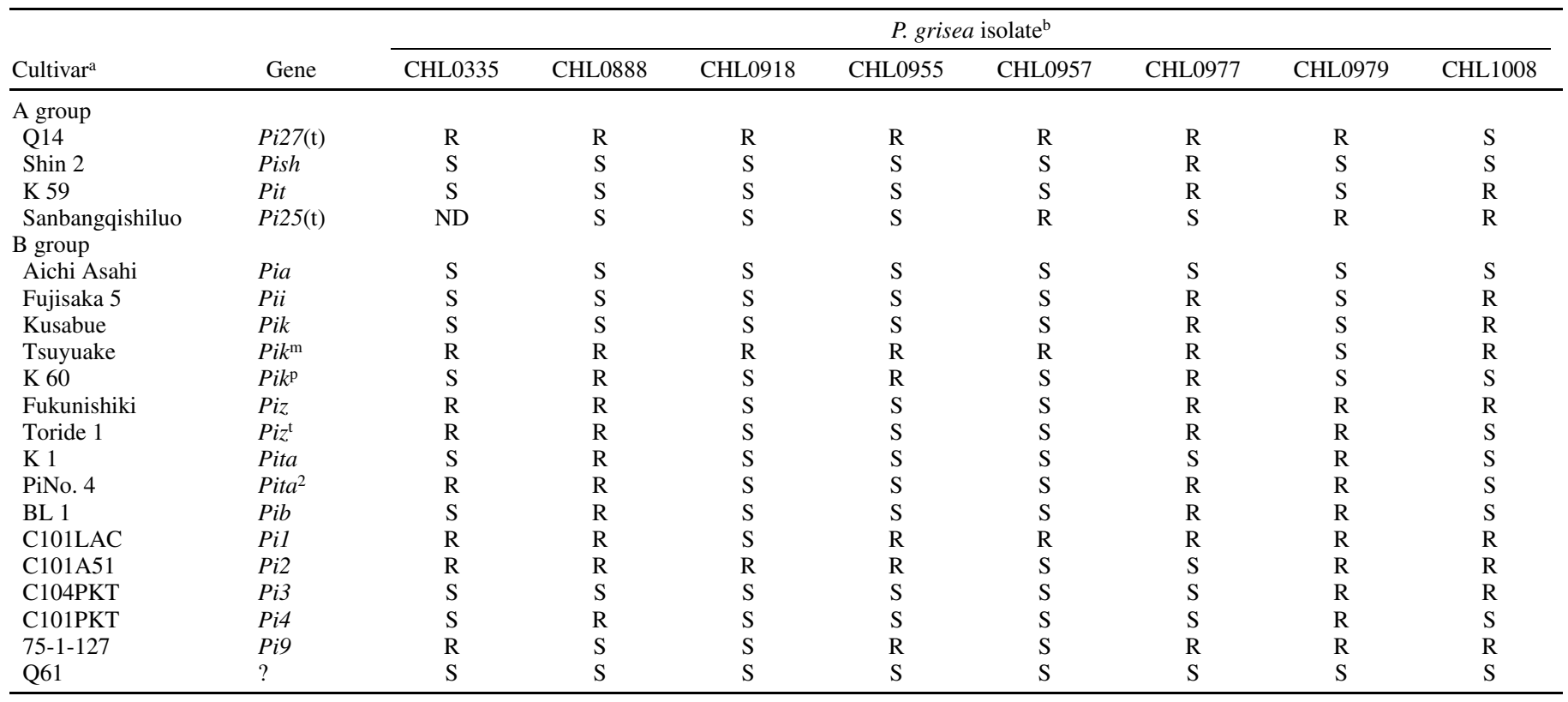

a A and B groups indicate resistance genes mapped on chromosome 1 and the other chromosomes, respectively.

${ }^{\mathrm{b}} \mathrm{R}=$ resistant, $\mathrm{S}=$ susceptible, and $\mathrm{ND}=$ not determined.

TABLE 2. Linkage analysis of the resistance gene Pi27(t) of Pyricularia grisea in a homozygous recessive population consisted of 155 highly susceptible rice plants selected from an $\mathrm{F}_{2}$ population derived from a cross between a Yunnan native resistant cv. Q14 and an indica-susceptible cv. Q61 using microsatellite markers

\begin{tabular}{|c|c|c|c|c|c|c|c|c|c|}
\hline \multirow[b]{2}{*}{ Gene pair } & \multirow[b]{2}{*}{ Linkage phase ${ }^{a}$} & \multicolumn{5}{|c|}{ Segregation model ${ }^{\mathrm{b}}$} & \multirow[b]{2}{*}{$\chi^{2}$ segregation $^{c}$} & \multirow[b]{2}{*}{$r \pm \mathrm{SE}^{\mathrm{d}}$} & \multirow[b]{2}{*}{$\operatorname{Map}(\mathrm{cM})^{\mathrm{e}}$} \\
\hline & & A-B- & A-bb & $\mathrm{aaB}-$ & $\mathrm{aabb}$ & Total & & & \\
\hline $\operatorname{Pi27}(\mathrm{t})-\mathrm{RM} 151$ & $\mathrm{C}$ & NT & NT & 37 & 118 & 155 & $213.4 * * *$ & $11.9 \pm 2.8$ & $12.1 \pm 3.0$ \\
\hline$P i 27(\mathrm{t})-\mathrm{RM} 259$ & $\mathrm{R}$ & NT & NT & 125 & 30 & 155 & $253.0 * * *$ & $9.7 \pm 8.0$ & $9.8 \pm 8.3$ \\
\hline RM151-RM259 & $\mathrm{R}$ & 25 & 18 & 100 & 18 & 155 & $228.9 * * *$ & $27.7 \pm 7.4$ & $31.2 \pm 12.1$ \\
\hline Pi27(t)-OSR3 & $\mathrm{C}$ & NT & NT & 108 & 47 & 155 & 2.1 & $\ldots$ & $\ldots$ \\
\hline
\end{tabular}

${ }^{a} \mathrm{C}=$ coupling phase and $\mathrm{R}=$ repulsion phase.

${ }^{\mathrm{b}} \mathrm{A}$ - or B- = resistant or the marker present; aa or $\mathrm{bb}=$ susceptible or the marker absent; $\mathrm{NT}=$ not tested.

${ }^{\mathrm{c}}$ Marker segregation; *** indicates significance at $P=0.001$ level for $\chi^{2}$.

${ }^{\mathrm{d}}$ Recombination frequency (percent) \pm standard error.

${ }^{\mathrm{e}}$ Distance in centimorgans (cM). 
polymerase chain reaction (PCR) System 9700 (PE Applied Biosystems, Foster City, CA). Primers of the microsatellite markers (36) were synthesized by Shanghai Sangon Biotechnology Co., Ltd. (Shanghai, China). The PCR procedures described by Temnykh et al. (36) were followed, with the exception that PCR products were separated on $6.0 \%$ polyacrylamide denaturing gels.

Identification of the resistance gene. BSA was performed to identify candidate markers linked to the resistance gene. Two contrasting bulks were prepared, each containing DNA from 25 resistant or susceptible $\mathrm{F}_{2}$ individuals. Candidate markers were confirmed by the RCA with 155 viable susceptible individuals derived from the $\mathrm{F}_{2}$ population. RCA was employed for verification because of the reliable reactions (diagnostic symptoms) and high efficiency to locate the gene on its chromosome $(21,24,40)$. By assuming that all 155 susceptible plants were homozygous for the recessive allele at the target gene locus, the recombination frequency $\left(r_{\mathrm{RM}}\right)$ between a marker and the resistance gene was calculated by the maximum likelihood method (3). Based on the molecular data from the 155 susceptible plants: $r_{\mathrm{RM}}=N_{\mathrm{aB}} / 2 N_{\mathrm{T}}$ in case of coupling phase and $r_{\mathrm{RM}}=N_{\mathrm{ab}} / 2 N_{\mathrm{T}}$ in case of repulsion phase, in which $N_{\mathrm{T}}$ is the total number of the susceptible individuals tested and $N_{\mathrm{aB}}$ and $N_{\mathrm{ab}}$ are the numbers of the susceptible individuals with and without a marker, respectively (Table 2). Likewise, the recombination frequencies $\left(r_{\mathrm{MM}}\right)$ among the markers linked to the resistance gene were estimated by the balance $r_{\mathrm{MM}}=N_{\mathrm{AB}}+N_{\mathrm{ab}} / 2 N_{\mathrm{T}}$, in which $N_{\mathrm{AB}}$ is the number of the susceptible individuals representing markers $\mathrm{A}$ and $\mathrm{B}$ (Table 2). The variance is given by $V_{\mathrm{r}}=1 / N_{\mathrm{T}} I_{\mathrm{r}}$, in which $I_{\mathrm{r}}$ is supplied according to Allard's Table 8 (3). The recombination frequency was transformed into centimorgans according to the Kosambi function (17).

\section{RESULTS}

Development of mapping population. In all, 1,147 $\mathrm{F}_{2}$ progenies derived from the cross of Q14 with Q61 were inoculated with the isolate CHL0335, which is avirulent to Q14 and virulent to Q61. Segregation of resistant (R) and susceptible (S) progenies fitted a 3:1 ratio in the $\mathrm{F}_{2}$ population (870R:277S, $\chi^{2}=0.40, P>$ 0.50 ), confirming that $\mathrm{Q} 14$ carries a single resistance gene to the isolate CHL0335. A population consisting of 25 resistant and 155 viable, susceptible individuals was constructed for subsequent gene mapping using molecular markers, because many susceptible individuals died when they were transplanted into pots.

Molecular mapping of the resistance gene. To determine chromosomal position of the resistance gene, a total of 189 microsatellite markers selected from 12 chromosomes with an intervals of $\approx 10$ centimorgans were tested through the BSA approach. The results showed that only two markers, RM151 and RM259, located on chromosome 1 showed positive (R) and negative (S) polymorphisms, respectively, for the resistance gene. To confirm the polymorphic markers, the plants consisting of the $\mathrm{R}$ and $\mathrm{S}$ gene pools were tested individually. The results showed that both markers cosegregated with the resistance gene (data not shown). For linkage analysis of the resistance gene with these two markers, a total of $155 \mathrm{~S}$ individuals, including those consisting of an S pool, were tested. The markers RM151 and RM259 were found to link to the resistance gene with recombination frequencies of $11.9 \pm 2.8 \%$ and $9.7 \pm 8.0 \%$, respectively (Table 2).

It is known that three other genes for blast resistance (e.g., Pit, Pish, and Pi25(t)) also were located in this region $(12,16,39)$. A comprehensive map of the putative resistance gene with these three resistance genes was constructed based on the data published (Fig. 1). This study clearly suggested that the locus identified in the present study is different from the three loci abovementioned. We, therefore, tentatively designated this new gene as $\operatorname{Pi27}(\mathrm{t})$.
Characterization of the new resistance gene $\mathrm{Pi27}(\mathrm{t})$. The resistance gene carrier Q14 showed high resistance to almost all Japanese and Thai isolates (Q. H. Pan, unpublished data), and has a broad resistance spectrum to Chinese isolates (a part of data shown in Table 1). To provide further evidence to distinguish the new resistance gene from the previously identified three resistance genes on chromosome 1, the first characterization of the new resistance gene was focused on the three resistance genes mentioned earlier. Four cultivars, including the parental cv. Q14, were subjected to differential tests with 85 isolates. The new resistance gene Pi27(t) showed distinct reactions from those conditioned by the three resistance genes (Table 1, A group).

To evaluate the effect of the new gene for blast resistance breeding, a further characterization of the new resistance gene was focused on comparison of the resistance spectrums between the new resistance gene and the main resistance genes that might be employed in the breeding program in China. Fifteen cultivars, each carrying a single resistance gene, were selected for differential tests using the 85 isolates. The results revealed that the new resistance gene conditions a broader and complementary resistance to the 15 important resistance genes (Table 1).

\section{DISCUSSION}

Yunnan Province in southwestern China is affluent in rice genetic resources $(25,37)$. Rice cultivars native to this region recently were investigated as a new source of blast resistance (20,22,38; Q. H. Pan unpublished data). Preliminary screening showed that many cultivars confer high resistance to many isolates that are virulent to cvs. carrying the $P i k^{\mathrm{m}}, P i z, P i z^{\mathrm{t}}, P i t a^{2}$,

\section{Distance (cM) Marker}

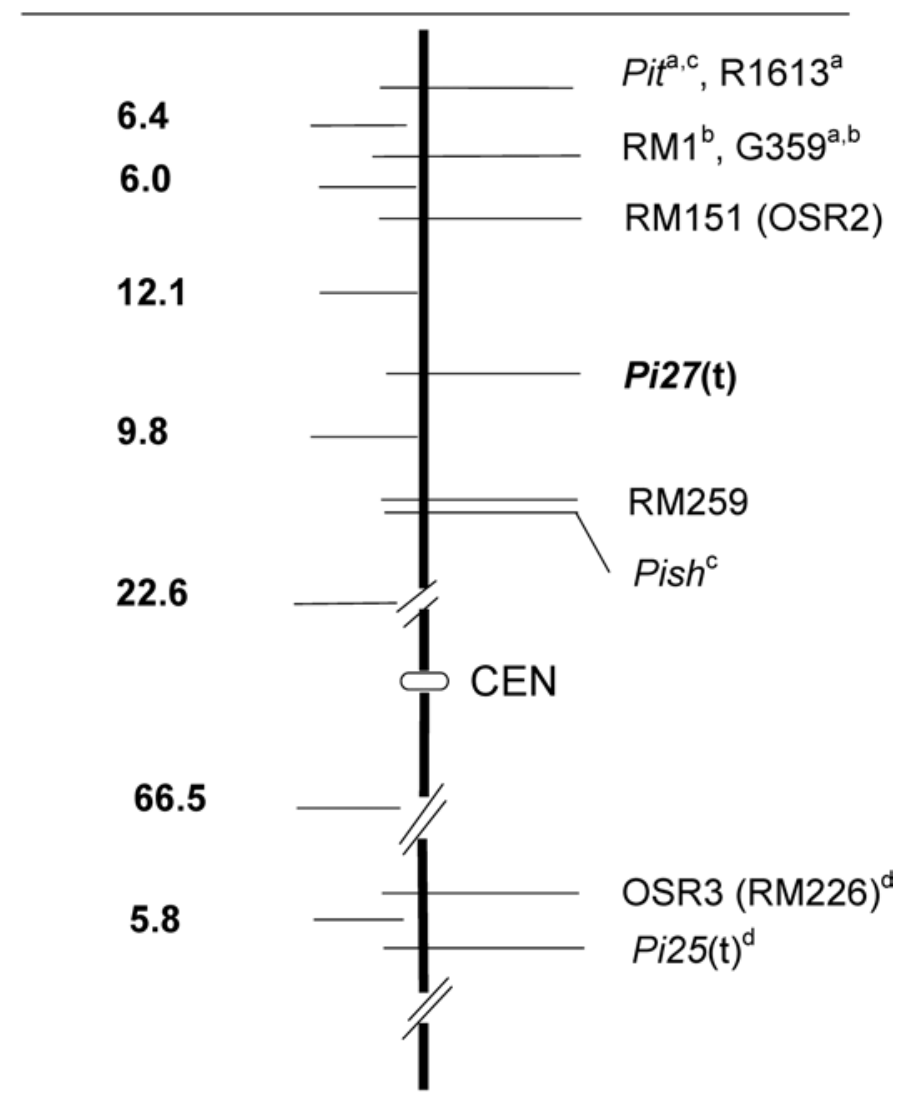

Fig. 1. Genetic map of four genes, Pit, Pi27(t), Pish, and Pi25(t), which confer resistance to blast on rice chromosome 1 . The locations of three genes other than $P i 27(\mathrm{t})$ identified in the present research were estimated based on the data from a, Kaji et al. (16); b, Akagi et al. (2); c, Imbe and Matsumoto (12); and d, Yang et al. (39). Map distances are in centimorgans (17). 
Pib, Pi2 (Piz ), and Pi9 genes (22; Q. H. Pan, unpublished data). Based on these studies, at least six new resistance genes, Pil3 and Pil4 (30), Pik and Pil5 (32), Pi25(t) (39), and the current resistance gene, $P i 27(\mathrm{t})$, have been identified so far.

In order to rapidly identify markers linked to resistance genes, Michelmore et al. (23) developed BSA to identify markers in the target genomic regions. With this method, DNA samples from resistant or susceptible plants from a segregating population are bulked separately. The comparison of two parental cultivars and bulks using molecular markers allows the identification of candidate markers linked to the target genes. However, the candidate markers should be confirmed by the phenotypic analysis of the segregating population. Following this, Zhang et al. (40) proposed a more cost-effective approach, RCA, which is particularly useful for mapping genes controlling expression of a complex trait. In this approach, chromosomal regions containing the target genes are identified through a bulked-extremes survey, and the chromosomal loci of the target genes are determined through linkage analysis using recessive-class individuals. Lin et al. (21) also applied this approach in mapping the chromosomal location of the gene $\mathrm{Xa22}$, conditioning resistance for rice bacterial blight disease, which cannot be distinctly separated into two contrasting groups. The recent work from our laboratory, including this study, provides further suggestions that the combination of BSA with RCA approaches may be especially useful for mapping resistance genes (28). First, there is a risk of mis-scoring of inoculationescaped plants as resistant individuals, even though the reactions controlled by target genes are identified clearly. Second, some susceptible plants which were heavily infected might not survive for subsequent gene mapping. In this study, out of 277 susceptible plants, only 155 plants were viable to take leaves for DNA extractions for linkage analysis using molecular markers.

Resistance genes tend to be clustered together on particular chromosomes $(14,15,34)$. Therefore, it is necessary to illustrate the relative map locations of resistance genes when a new resistance gene is mapped into the cluster. We carefully reviewed other loci of rice blast resistance genes mapped on chromosome 1 and constructed a comprehensive map of rice blast resistance genes located on chromosome 1 (Fig. 1).

The new resistance gene $P i 27(\mathrm{t})$ conditions distinct reactions from those conditioned by the known resistance gene located on chromosome 1. Moreover, Pi27(t) also conditions clear resistance against isolates that are virulent to the main resistance genes employed in the current breeding program in Guangdong Province, indicating that $P i 27(\mathrm{t})$ might be a new resistance source for the resistance breeding program. As an application to the breeding program through an MAS approach $(10,11,26)$, we are undertaking to finely map the resistance gene with other molecular markers, such as sequence-tagged site (STS) and cleaved amplified polymorphic sequence (CAPS) markers.

\section{ACKNOWLEDGMENTS}

This research was supported by the grants from the National Program for High Technology Research and Development of China (2001AA222231), the National Special Program for Functional Genomics and Biologic Chips (2002AA2Z1002), and the Guangdong Provincial Natural Science Foundation (000575; 039254).

\section{LITERATURE CITED}

1. Ahn, S. N., Kim, Y. K., Hong, H. C., Han, S. S., Kwon, S. J., Choi, H. C., Moon, H. P., and McCouch, S. R. 2000. Molecular mapping of a new gene for resistance to rice blast (Pyricularia grisea Sacc.). Euphytica 116:17-22.

2. Akagi, H., Yokozeki, Y., Inagaki, A., and Fujimura, T. 1996. Microsatellite DNA markers for rice chromosomes. Theor. Appl. Genet. 93:1071-1077.

3. Allard, R. W. 1956. Formulas and tables to facilitate the calculation of recombination values in heredity. Hilgardia 24:235-278.
4. Chen, X. W., Xu, J., Li, S., Li, X., and Zhu, L. 2001. Towards cloning a blast resistance gene $P i-d 2(\mathrm{t})$ in rice Digu. Page 1 in: Proc. General Meeting Rice Blast in China, Kunming.

5. Disthaporn, S. 1994. Current rice blast epidemics and their management in Thailand. Pages 333-342 in: Rice Blast Disease. R. S. Zeigler, S. A. Leong, and P. S. Teng, eds. CAB International, Wallingford, UK.

6. Doyle, J. J., and Doyle, J. L. 1990. Isolation of plant DNA from fresh tissue. Focus 12:13-15.

7. Fomba, S. N., and Taylor, D. R. 1994. Rice blast in West Africa: Its nature and control. Pages 343-355 in: Rice Blast Disease. R. S. Zeigler, S. A. Leong, and P. S. Teng, eds. CAB International, Wallingford, UK.

8. Fujii, K., Hayano-Saito, Y., Saito, K., Sugiura, N., Hayashi, N., Tsuji, T., Izawa, T., and Iwasaki, M. 2000. Identification of a RFLP marker tightly linked to the panicle blast resistance gene, $P b 1$, in rice. Breed. Sci. 50:183-188.

9. Fukuoka, S., and Okuno, K. 2001. QTL analysis and mapping of pi21, a recessive gene for field resistance to rice blast in Japanese upland rice. Theor. Appl. Genet. 103:185-190.

10. Hittalmani, S., Foolad, M. R., Mew, T., Rodriguez, R. L., and Huang, N. 1995. Development of a PCR-based marker to identify rice blast resistance gene, $P i-2(\mathrm{t})$, in a segregation population. Theor. Appl. Genet. 91:9-14.

11. Huang, N., Angeles, E. R., Domingo, J., Magpantay, G., Singh, S., Zhang, G., Kumaravadivel, N., Bennett, J., and Khush, G. S. 1997. Pyramiding of bacterial blight resistance genes in rice: Marker-assisted selection using RFLP and PCR. Theor. Appl. Genet. 95:313-320.

12. Imbe, T., and Matsumoto, S. 1985. Inheritance of resistance of rice varieties to the blast fungus strains virulent to the variety "Reiho". Jpn. J. Breed. 35:332-339. (In Japanese with English summary)

13. Imbe, T., Oba, S., Yanoria, M. J. T., and Tsunematsu, H. 1997. A new gene for blast resistance in rice cultivar, IR24. Rice Genet. Newsl. 14:6062.

14. Inukai, T., Nelson, R. J., Zeigler, R. S., Sarkarung, S., Mackill, D. J., Bonman, J. M., Takamure, I., and Kinoshita, T. 1994. Allelism of blast resistance genes in near-isogenic lines of rice. Phytopathology 84:1278-1283.

15. Islam, M. R., and Shepherd, K. W. 1991. Present status of genetics of rust resistance in flax. Euphytica 55:255-267.

16. Kaji, R., Ogawa, T., and Nishimura, M. 1997. RFLP mapping of a blast resistance gene, Pit, in rice. Breed. Sci. (Suppl. 1) 47:37.

17. Kosambi, D. D. 1944. The estimation of map distances from recombination values. Ann. Eugen. 12:172-175.

18. Leong, S. A., Chanhan, R. S., Farman, M. L., Tosa, Y., Mayama, S., Eto, Y., Nakayashiki, H., Ronald, P., Zhang, H. B., and Puneker, N. S. 1999. Molecular genetic analysis of the interaction of Magnaporthe grisea (AVR1-CO39) and indica rice CO39. Page 76 in: Abstr. General Meeting Int. Program Rice Biotechnol. Phuket, Thailand.

19. Li, S. G., Ma, Y., Wang, Y., Wang, W., Zhou, K., and Zhu, L. 2000. Genetic analysis and mapping of a resistance gene in an indica cultivar Digu. Progr. Nat. Sci. 10:44-48. (In Chinese)

20. Liang, B., Peng, S., Xiao, F., Huang, F., Chen, Y., Liu, E., and Yu, T. 2001. Study on the resistance to rice blast of Yunnan Conventional rice germplasms. Chin. J. Rice Sci. 15:147-150. (In Chinese with English summary)

21. Lin, X. H., Zhang, D., Xie, Y., Gao, H., and Zhang, Q. 1996. Identification and mapping a new gene for bacterial blight resistance in rice based on RFLP markers. Phytopathology 86:1156-1159.

22. Ling, Z., Wang, J., Pan, Q. H., Li, M., Huang, Q., and Qiu, Z. 1990. Classification for blast resistance of some Japonica type varieties from Yunnan Province. Sci. Agric. Sin. 23:5-11. (In Chinese with English summary)

23. Michelmore, R. W., Paran, I., and Kesseli, R. V. 1991. Identification of markers linked to disease-resistance genes by bulked segregant analysis: A rapid method to detect markers in specific genomic regions by using segregating populations. Proc. Natl. Acad. Sci. USA 88:9828-9832.

24. Miyamoto, M., Ando, I., Rybka, K., Kodama, O., Kawasaki, S. 1996. High resolution mapping of the Indica-derived rice blast resistance genes. I. Pi- $b$. Mol. Plant-Microbe Interact. 9:6-13.

25. Nakagahra, M. 1985. Native Place of Rice and Rice Growing. Koinn Shoinn, Tokyo. (In Japanese)

26. Naqvi, N. I., and Chattoo, B. B. 1996. Development of a sequence characterized amplified region (SCAR) based indirect selection method for a dominant blast-resistance gene in rice. Genome 39:26-30.

27. Ou, S. H. 1985. Pages 109-201 in: Rice Diseases. 2nd ed. Commonwealth Mycological Institute, Kew, Surrey, UK.

28. Pan, Q. H., Hu, Z., Tanisaka, T., and Wang, L. 2003. Fine mapping of the blast resistance gene Pi15, linked to Pii, on rice chromosome 9. Acta Bot. Sin. 45:871-877.

29. Pan, Q. H., Wang, L., Ikehashi, H., and Tanisaka, T. 1996. Identification of a new blast resistance gene in the indica rice cultivar Kasalath using Japanese differential cultivars and isozyme markers. Phytopathology 86:1071-1075. 
30. Pan, Q. H., Wang, L., Ikehashi, H., Yamagata, H., and Tanisaka, T. 1998. Identification of two new genes conferring resistance to rice blast in the Chinese native cultivar 'Maowangu'. Plant Breed. 117:27-31.

31. Pan, Q. H., Wang, L., and Tanisaka, T. 1999. A new blast resistance gene identified in the Indian native rice cultivar Aus373 through allelism and linkage tests. Plant Pathol. 48:288-293.

32. Pan, Q. H., Wang, L., Tanisaka, T., and Ikehashi, H. 1998. Allelism of rice blast resistance genes in two Chinese native cultivars and identification of two new resistance genes. Plant Pathol. 47:165-170.

33. Shen, M., and Lin, J. Y. 1994. The economic impact of rice blast disease in China. Pages 321-331 in: Rice Blast Disease. R. S. Zeigler, S. A. Leong, and P. S. Teng, eds. CAB International, Wallingford, UK.

34. Sudupak, M. A., Bennetzen, J. L., and Hulbert, S. H. 1994. Unequal exchange and meiotic instability of disease-resistance genes in the $R p 1$ region of maize. Genetics 133:119-125.

35. Tabien, R. E., Li, Z., Paterson, A. H., Marchetti, M. A., Stansel, J. W., and Pinson, S. R. M. 2000. Mapping of four major rice blast resistance genes from 'Lemont' and 'Teqing' and evaluation of their combinatorial effect for field resistance. Theor. Appl. Genet. 101:1215-1225.

36. Temnykh, S., Park, W. D., Ayres, N., Cartinhour, S., Hauck, N., Lipovich, L., Cho, Y. G., Ishii, T., and McCouch, S. R. 2000. Mapping and genome organization of microsatellite sequences in rice (Oryza sativa L.). Theor Appl. Genet. 100:697-712.

37. Wang, X. 1993. Origin, evolution and classification of the cultivated rice in China. Pages 1-6 in: Rice Germplasm Resources in China. C. Ying, ed. Agricultural Science-Technology Publishing House, Beijing. (In Chinese)

38. Xiao, F., Chen, Y., Peng, S., Xiao, Y., Liang, B., Liu, E., and Huang, F. 2001. Application of cluster analysis on screening rice varieties with durable resistance to rice blast. Chin. J. Rice Sci. 15:225-228.

39. Yang, Q., Saito, K., Yang, P., Wang, Q., Sunohara, Y., Zheng, F., Ye, C., Li, J., and Kato, A. 2001. Molecular mapping of a new blast resistance gene Pi25(t) possessed in a Japonica rice cultivar, Oryza sativa L. cv. Yunxi 2. Pages 49-55 in: Proc. General Meeting Rice Blast in China, Kunming.

40. Zhang, Q., Shen, B. Z., Dai, X. K., Mei, M. H., Saghai-Maroof, M. A., and $\mathrm{Li}, \mathrm{Z}$. B. 1994. Using bulked extremes and recessive class to map genes for photoperiod-sensitive genic male sterility in rice. Proc. Natl. Acad. Sci. USA 91:8675-8679.

41. Zhuang, J., Wu, J., Chai, R., Fan, Y., Jin, M., Leung, H., and Zheng, K. 1999. DNA markers based gene mapping for leaf and neck blast resistance and verification of gene effects in rice. Page 297 in: Abstr. General Meeting Int. Program Rice Biotechnol. Phuket, Thailand. 